\section{Synthesis of hybrid materials based on layered double hydroxides}

${ }^{1}$ Nestroinaia O.V.*, ${ }^{2}$ Ponomarenko O.I.

${ }^{1}$ Belgorod State University, Belgorod, Russia ${ }^{2} \mathrm{Al}$-Farabi Kazakh National University, Almaty, Kazakhstan *E-mail: nestroynaya91@gmail.com
The use of pesticides adversely affects not only the environment, but also human health. A promising direction in solving this problem is to obtain hybrid materials capable of controlled release of pesticides. Layered double hydroxides (LDHs) can act as a matrix. Layered double hydroxides with intercalated glyphosate anions (MgAl-Gly-LDH) were synthesized by different methods: coprecipitation at constant $\mathrm{pH}$ (MgAl-Gly-LDH-c), synthesis under hydrotherma conditions (MgAl-Gly-LDH-ht), microwave method (MgAl-Gly-LDH-mw) and rehydration method (MgAl-Gly-LDH-re). All the synthesized samples were analyzed by X-ray phase analysis (XRD) energy dispersive X-ray spectroscopy, scanning electron microscopy, Fourier transform infrared spectroscopy and Raman spectroscopy. It is shown that the methods of co-precipitation and synthesis under hydrothermal conditions are most suitable for the synthesis of hybrid materials. Samples of MgAl-Gly-LDH-ht and MgAl-Gly-LDH-c have a well-crystallized structure, unlike the sample of MgAl-Gly-LDH-re, in which the LDH phase is practically absent.

Keywords: layered double hydroxides; intercalation; glyphosate; hydrothermal synthesis microwave synthesis.

\section{Қабатты қос гидроксидтердің негізіндегі гибридті материалдардын синтезі}

${ }^{1}$ Нестройная О.В.*, ${ }^{2}$ Пономаренко О.И.

${ }^{1}$ Белгород Мемлекеттік ұлттық зерттеу университеті, Белгород, Казақстан 2Әл-Фараби атындағы Қазақ ұлттық университеті, Алматы, Казақстан *E-mail: nestroynaya91@gmail.com
Петицидтерді қолдану тек қоршаған ортаға ғана емес адамның денсаулығына да әсерін тигізеді. Бұл мәселені шешудің перспективті бағыты пестицидтерді бақылай отырып босата алатын гибридті материалдарды алу болып табылады. Матрица ретінде қатпарлы қос гидроксидтер (ҚҚГ) қолданылуы мүмкін. Глифосфаттың (MgAl-Gly- LDH) аниондарымен интеркалибрленген қатпарлы қос гидрокидтер түрлі әдіспен синтезделді: тұрақты pH (MgAl-Gly-LDH-c) бірге тұндыру, гидротермальді жағдайларда синтездеу (MgAlGly-LDH-ht), микротолқынды әдіс (MgAl-Gly-LDH-mw) және регидратация әдісі (MgAl-GlyLDH-re). Барлық синтезделген үлгілер рентгенофазалық талдау, энергодисперсиялық рентгендік спектрокопия, сканерлеуші электрондық микроскопия, Фурье түрлендіруші энергодисперсті инфрақызыл спектрокопия және біріге таралу спектроскопиясымен талдау жасалды. Гибридті материалдарды синтездеудің ең қолайлысы бірге тұндыру әдісі және гидротермальді жағдайларда синтездеу болатыны анықталды. MgAl-Gly-LDH re үлгісімен салыстырғанда MgAl-Gly-LDH-ht және MgAl-Gly-LDH-с үлгілерінің құрылымы жақсы кристалданған, онда ҚҚГ фазасы мүлдем жоқ.

Түйін сөздер: қатпарлы қос гидроксидтер; интеркаляция; глифосат; гидротермиялық синтез; микротолқынды синтез.

\section{Синтез гибридных материалов на основе слоистых двойных гидроксидов}

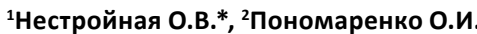

Белгородский государственный национальный исследовательский университет, Белгород, Россия ${ }^{2}$ Казахский национальный университет имени аль-Фараби, Алматы, Казахстан

*E-mail: nestroynaya91@gmail.com
Применение пестицидов пагубно влияет не только на окружающую среду, но и на здоровье человека. Перспективным направлением в решении данной проблемы является получение гибридных материалов, способных к контролируемому высвобождению пестицидов. В качестве матрицы могут выступать слоистые двойные гидроксиды (СДГ). Слоистые двойные гидроксиды с интеркалированными анионами глифосата (MgAl-GlyLDH) были синтезированы разными методами: соосаждение при постоянном pH (MgAlGly-LDH-c), синтез в гидротермальных условиях (MgAl-Gly-LDH-ht), микроволновый метод (MgAl-Gly-LDH-mw) и метод регидратации (MgAl-Gly-LDH-re). Все синтезированные образцы были проанализированы рентгенофазовым анализом, энергодисперсионной рентгеновской спектроскопией, сканирующей электронной микроскопией, инфракрасной спектроскопией с Фурье преобразованием и спектроскопией комбинационного рассеяния. Показано, что наиболее подходящими для синтеза гибридных материалов являются метод соосаждения и синтез в гидротермальных условиях. Образцы MgAl-Gly-LDH-ht и MgAl-GlyLDH-с обладают хорошо окристаллизованной структурой, в отличие от образца MgAl-GlyLDH-re, у которого фаза СДГ практически отсутствует.

Ключевые слова: слоистые двойные гидроксиды; интеркаляция; глифосат; гидротермальный синтез; микроволновый синтез. 


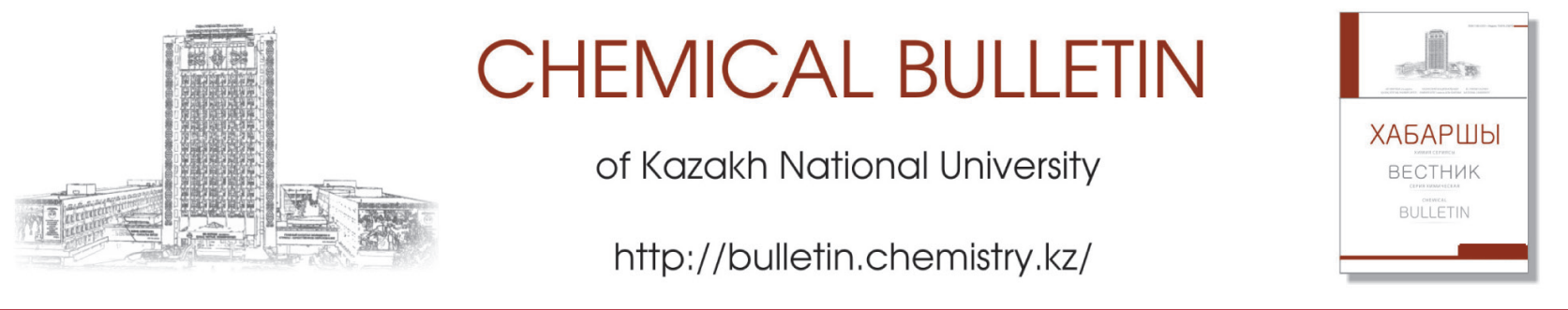

UDC 54.057

https://doi.org/10.15328/cb1025

\title{
Synthesis of hybrid materials based on layered double hydroxides
}

\author{
${ }^{1}$ Nestroinaia O.V.*, ${ }^{2}$ Ponomarenko O.I. \\ ${ }^{1}$ Belgorod State University, Belgorod, Russia \\ ${ }^{2} \mathrm{Al}$-Farabi Kazakh National University, Almaty, Kazakhstan \\ *E-mail: nestroynaya91@gmail.com
}

\section{Introduction}

Advances in plant protection through the use of pesticides have made a significant contribution to increasing yields and ensuring stable agricultural production. Unfortunately, along with the obvious advantages, there are some disadvantages, in particular, the risk of environmental pollution.

For example, one of the most popular herbicides in the world is glyphosate. It is widely used not only for the destruction of a large number of harmful plants in agriculture, but also for the cultivation of modified crops [1]. Thus, we can conclude that glyphosate enters not only into the environment, but also into the human body along with food and water. Systematic or periodic release of pesticides into the human body, even in small quantities, has various negative effects on human health. Controlled pesticide release technology is an effective tool for solving this problem.

In a number of publications, in order to reduce the risk for the environment, it is proposed to use natural and synthetic inorganic compounds to encapsulate pesticides in order to obtain controlled release composite materials. Examples of such materials are inorganic and organically modified silicate clays, zeolites and polymers.

The interest in layered double hydroxides (LDHs) as matrices for the storage and slow release of chemicals of various nature is due to the specific structure and unique properties of these materials.

LDHs are layered materials with the general formula, where $\mathrm{M}^{2+}$ and $\mathrm{M}^{3+}$ - metal ions in the octahedral positions of brucite-like layers, An-inorganic or organic anions that compensate for the positive charge of brucite-like layers [2]. Features of the structure of hydrotalcite-like compounds provide their specific ion-exchange, sorption, electrical and magnetic properties. Excess positive charge of brucite-like layers is compensated by anions located in the interlayer space $[2,3]$. Interlayer anions are easy to exchange, that allows to modify LDH and regulate their properties.

The intercalation of organic anions into the structure of LDH can be carried out in various ways. The advantage of using LDHs as carriers of pesticides lies not only in their ability to ion exchange, which makes them an excellent matrix for transferring labile pesticides, but also due to the basic nature of LDHs, they have a favorable effect on many cultivated soils with increased acidity. In addition, pesticides intercalated between brucite-like layers can be reliably protected from biological, chemical and thermal damage in soils. In such systems, a synergistic effect can also be observed, which is manifested in an increase in the activity of the intercalated drug.

In this paper, composite materials based on the LDH as glyphosate's carrier were obtained. Previously, $\mathrm{Ni}_{2} \mathrm{Al}-\mathrm{LDH}$ and MgAl - LDH were synthesized with intercalated glyphosate by co-precipitation method [4]. For the synthesis, the most common methods as co-precipitation and anion exchange were used. In our own work, we studied the possibility of synthesizing combined materials using the hydrothermal method, the microwave method and rehydration method ("memory effect").

\section{Experiment}

\subsection{Preparation of samples}

Hybrid materials based on layered double hydroxides and glyphosate anions (MgAl-Gly-LDH) were obtained by using four different methods of synthesis: co-precipitation, rehydration, hydrothermal and microwave. A sample of LDH was also synthesized in the nitrate form ( $\left.\mathrm{MgAl}-\mathrm{NO}_{3}-\mathrm{LDH}\right)$. 
Nitrates of corresponding metals were used for the synthesis of the samples, as well as sodium hydroxide and glyphosate. All reagents were pure for analysis.

$\mathrm{MgAl}-\mathrm{NO}_{3}-\mathrm{LDH}$ was synthesized by coprecipitation. This method is now considered as the most common in the synthesis of LDH. This is due to the fact that it has become possible to obtain well crystallized and pure phase materials. Magnesium and aluminum nitrates in a molar ratio of $\mathrm{Mg}: \mathrm{Al} \mathrm{3:1}$ were dissolved in $150 \mathrm{~mL}$ of distilled water and $100 \mathrm{~mL}$ of a precipitating solution $(\mathrm{NaOH})$ were gradually added to this solution.The total concentration of ions in the solution was approximately equal to $1 \mathrm{M}$. The $\mathrm{pH}$ of the mixture was constantly kept $(\mathrm{pH}=10.0 \pm 0.1)$. The precipitate was given aging at $98^{\circ} \mathrm{C}$ for $48 \mathrm{~h}$. The obtained sample was well washed with distilled water from impurities and dried at $120^{\circ} \mathrm{C}$.

MgAl-Gly-LDH was also obtained by using the coprecipitation method (MgAl-Gly-LDH-c). Previously, this method was received by the [5] group. Metal nitrates were added to $150 \mathrm{~mL}$ of glyphosate solution, which was taken in the triple - excessed relative to aluminum ions $\mathrm{Al}^{3+}$. Next, solutionprecipitant was added to the mixture. During synthesis, the $\mathrm{pH}$ of the system did not exceed 9-10. The aging process of the precipitate and its washing were held under identical conditions.

MgAl-Gly-LDH was synthesized by method of rehydration (MgAl-Gly-LDH-re). This method implies a study of the "memory effect" or the ability of layered double hydroxides to restore their structure. The synthesized sample $\mathrm{MgAl}-\mathrm{NO}_{3}-\mathrm{LDH}$ was subjected to heat treatment at a temperature of $500^{\circ} \mathrm{C}$ for $1 \mathrm{~h}$. As a result, a mixture of oxides was obtained. Then this mixture was poured with glyphosate solution and was constantly stirred for $24 \mathrm{~h}$. A day later, the sample was dried at $100^{\circ} \mathrm{C}$.

Also MgAl-Gly-LDH was synthesized under hydrothermal conditions (MgAl-Gly-LDH-ht). This method allows to obtain fine powders with a crystallized layered structure. This synthesis was carried out for two days in Autoclave Engineers Parker at $140^{\circ} \mathrm{C}$ at a constant $\mathrm{pH}$ level. The concentration of metal ions in the solution was $1 \mathrm{M}$. Glyphosate, as in the method of coprecipitation, was taken in triple-excessed relating to aluminum.

The last sample of MgAl-Gly-LDH was synthesized under microwave irradiation (MgAl-Gly-LDH-mw). This method is interesting because it is possible to reduce the time of formation of the structure significantly. This synthesis was carried out in MARS- 6 reactor with a microwave exposure time of $3 \mathrm{~min}$ and a power of $700 \mathrm{~W}$. The composition of the reaction mixture did not change compared with the previous methods.

\subsection{Characterization}

X-ray phase analysis (XRD) was used to identify the structure and phase composition of the synthesized samples on Rigaku diffractometer (CuK $\alpha$ radiation) with a scan step of $2 \theta 0.02^{\circ}$. The analysis was performed by the powder method (Debye-Scherrer-Hell's method). Sample preparation consists of the grinding of LDH samples in an agate mortar to a powdery state.
The study of the morphology of the samples was held by scanning electron microscopy using a HITACHI SU1510 microscope at an operating voltage of $200 \mathrm{kV}$. For analysis, the samples were ground to a powder and applied to a carbon film.

Elemental analysis of metal and phosphorus cations in samples of LDHs was performed by an FEI Quanta 200 3D scanning electron microscope equipped with an energy dispersive X-ray analysis (EDAX) system at an operating voltage of $30 \mathrm{kV}$.

The IR spectra of the samples were recorded in the range of $4500-450 \mathrm{~cm}^{-1}$ using a Shimadzu IR Prestige 21 FT-IR spectrometer. Registration was performed for a mixture of samples with potassium bromide.

Raman spectra were collected in backscattering mode using LabRAM HR Evolution spectrometer (Horiba, Japan), with excitation at $525 \mathrm{~nm}$ from a helium-neon ion laser. The scanning scope traversed between a Raman Shift of $500 \mathrm{~cm}^{-1}$ and $4500 \mathrm{~cm}^{-1}$, and only one accumulative number of times was arranged.

\section{Results and Discussion}

X-ray diffraction patterns of samples of LDH obtained by different methods are shown in Figure 1. All synthesized samples may be identified as layered double hydroxides, since powder X-ray diffraction patterns are common to this class of compounds. The obtained patterns of samples exhibit the basal peaks (003), (006), (009/012), (015), (018), (110) and (113), which confirm the formation of LDH structure. The reflexes corresponding to the basal reflections (110) and (113) form a doublet at approximately 62 degrees, which is also common to hydrotalcite-like compounds. Excepting MgAl-Gly-LDH-mw sample, which is a fixed singlet, that indicate a low crystallinity of structure.

It should be noted that there is a slight displacement of the first peak of intercalates in the area of small angles of 2theta. This fact may be the proof of the successful intercalation of glyphosate in structure of $\mathrm{LDH}$. However, in spite of a good crystallized structure, impurity phases $\left(\mathrm{Al}_{2} \mathrm{O}_{3}, \mathrm{Al}(\mathrm{OH})_{3}\right)$ are present in the samples MgAl-Gly-LDH-ht and MgAl-Gly-LDH-c.

The sample MgAl-Gly-LDH-re has the lowest crystallinity. The X-ray diffraction pattern shows that the structure of the LDH is partially restored, the phases are difficult to distinguish and therefore it is rather difficult to speak about intercalation.

Comparing the X-ray diffraction patterns of the samples obtained by different methods, one can note that the most intense and narrow reflexes are observed for LDH synthesized in the hydrothermal conditions (Figure 2). Quite narrow peaks, high intensity values and a well-split doublet indicate a high crystallinity of the samples. The samples obtained by the coprecipitation method are slightly less crystallized.

The least successful was the synthesis of the LDH sample by dehydration - rehydration method. It was assumed that the mixture of oxides obtained after calcination of $\mathrm{Mg}-\mathrm{Al}-\mathrm{NO}_{3}-\mathrm{LDH}$ will be able to return the layered structure when interacting 


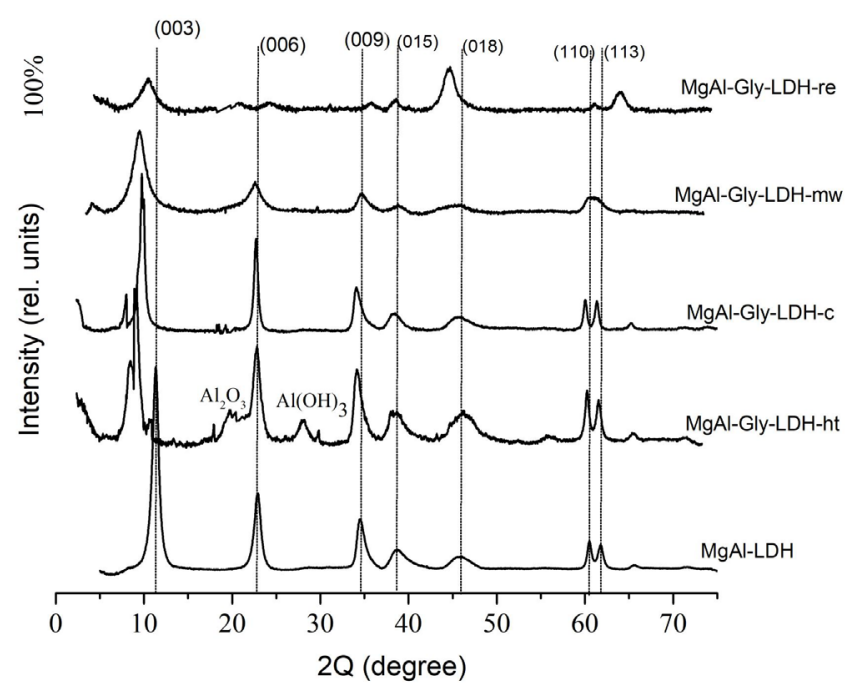

Figure 1 -X-ray diffraction patterns of synthesized samples

with aqueous glyphosate. It has been suggested that glyphosate intercalation will occur in parallel with the regeneration of the layered structure. Figure 2 shows the diffraction patterns for a mixture of oxides ( $\mathrm{MgO}$ and $\mathrm{Al}_{2} \mathrm{O}_{3}$ ) after calcination and LDH after rehydration. However, it turned out that the structure is restored only partially. There are no peaks that are characteristical of hydrotalcites and the intensity of the reflections on the $\mathrm{X}$-ray diffraction patterns is low, which indicates a low content of the LDH phase in the sample.

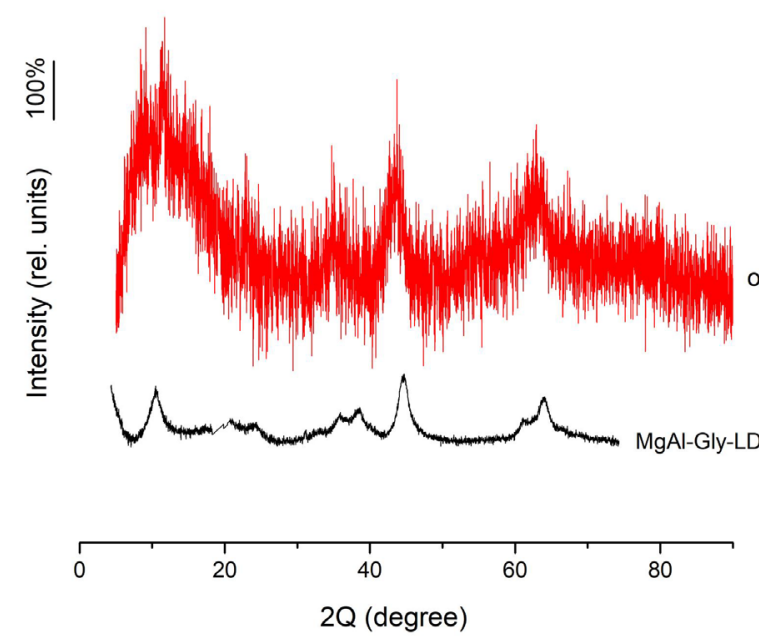

Figure 2 - X-ray diffraction patterns of MgAl-Gly-LDH-re and oxides

The parameters $c$ and $a$ of the crystal lattice of LDH were calculated according to XRD data (Table 1). The parameter $c$, which characterizes the interlayer distance, was calculated by the formulas $c=3 d(003)$ [6]. The parameter $a$ is equal to the distance between adjacent cations in a brucite-like layer. It is calculated as $a=2 d(110)$ [6].

According to the results of elemental analysis (Table 1 ), it is shown that in the samples synthesized by co-precipitation and under hydrothermal conditions, the molar ratios are equal to the theoretically calculated ones. In a microwave synthesized sample, the molar ratio is slightly lower than in the theoretical one. Value of parameter $c$ is correlated with the results of elemental analysis.

Table 1 - Metal atom fractions and crystal lattice parameters of the LDHs calculated from EDAX and XRD data

\begin{tabular}{cccc}
\hline Sample & c, A & a, A & $\begin{array}{l}\text { Mg/Al/P/N } \\
\text { molar ratio }\end{array}$ \\
\hline MgAl-NO_-LDH & 22.5 & 3.06 & $2.5: 1: 0: 1$ \\
MgAl-Gly-LDH-ht & 27.3 & 3.09 & $2: 1: 0.4: 0.4$ \\
MgAl-Gly-LDH-c & 26.1 & 3.07 & $2: 1: 0.33: 0.33$ \\
MgAl-Gly-LDH-mw & 22.3 & 3.06 & $1.7: 1: 0.25: 0.25$ \\
MgAl-Gly-LDH-re & - & 3.06 & $1.2: 0.7: 0.02: 0.1$ \\
\hline
\end{tabular}

The morphology of the synthesized samples was assessed by scanning electron microscopy (SEM). Figure 3 shows a SEM micrographs of the synthesized hybrid material. Large particles with a good layered structure are observed in the photo. Micrographs show clearly separated layers. Generally, the morphology of the ground sample without water exhibits agglomeration of fine particles in several microns, though the size of primary particles is in nanoscale. The water existence leads to a further agglomeration into large particles [7]. 


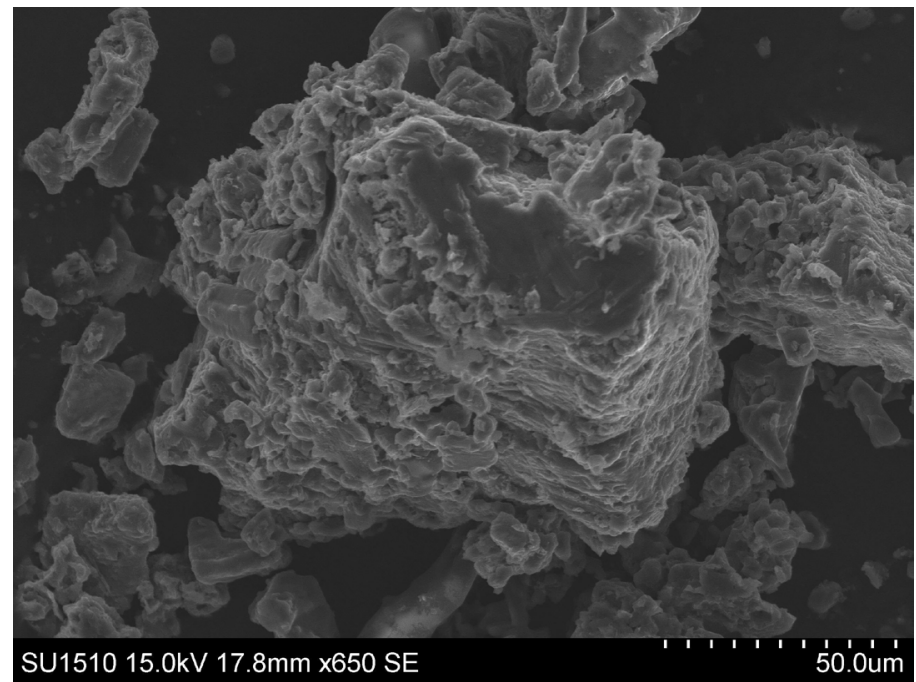

Figure 3 - SEM micrographs of the MgAl-Gly-LDH-ht

The additional information on the structure of the synthesized hybrid materials was obtained by the method of IRspectroscopy. Using this method, it was possible to confirm the intercalation of glyphosate into the MgAl-LDH structure. The obtained IR spectra are characteristic of hydrotalcite-like compounds (Figure 4). However, on the IR spectra of the samples, there are also extraneous peaks, which can be evidence of the intercalation of glyphosate into the structure of the LDH. The IR spectra of LDHs are characterized by the presence of a broad intense band with a maximum in the range of $3480-3600 \mathrm{~cm}^{-1}$, which corresponds to the vibrations of hydroxides in metal hydroxide layers and $\mathrm{H}_{2} \mathrm{O}$ molecules in the interlayer space. The presence of a weak shoulder in the range of $3060-3100 \mathrm{~cm}^{-1}$ and at $1650-1670 \mathrm{~cm}^{-1}$ indicates vibrations related to the $-\mathrm{OH}$ groups of water molecules born by hydrogen bonds to carbonate anions. However, a shoulder at 1630-1800 with maxima at $1650 \mathrm{~cm}^{-1}$ can indicate a $\mathrm{C}=0$ bond, and a low intensity band in the area of $2250-2375 \mathrm{~cm}^{-1}$ is usually referred to atmospheric $\mathrm{CO}_{2}$. The splitting of the band related to the position for free carbonate anions $\left(1480-1500 \mathrm{~cm}^{-1}\right)$ is due to decreasing in the symmetry of anions as a result of interaction with interlayered water molecules and/or hydroxyl groups of brucite-like layers. The absorption band with a maximum at $\sim 1380 \mathrm{~cm}^{-1}$ corresponds to the vibrations of the $\mathrm{NO}_{3}{ }^{-}$group [9], which in turns corresponds to antisymmetric stretching vibrations and is pronounced due to the presence of carbonate anions in the interlayer space. In samples with intercalated glyphosate, the band disappears at $1380 \mathrm{~cm}^{-1}$. Perhaps this is due to the displacement of the group $\mathrm{NO}_{3}$. Shoulder broadening in the range from $1250-1500 \mathrm{~cm}^{-1}$ is also explained by the

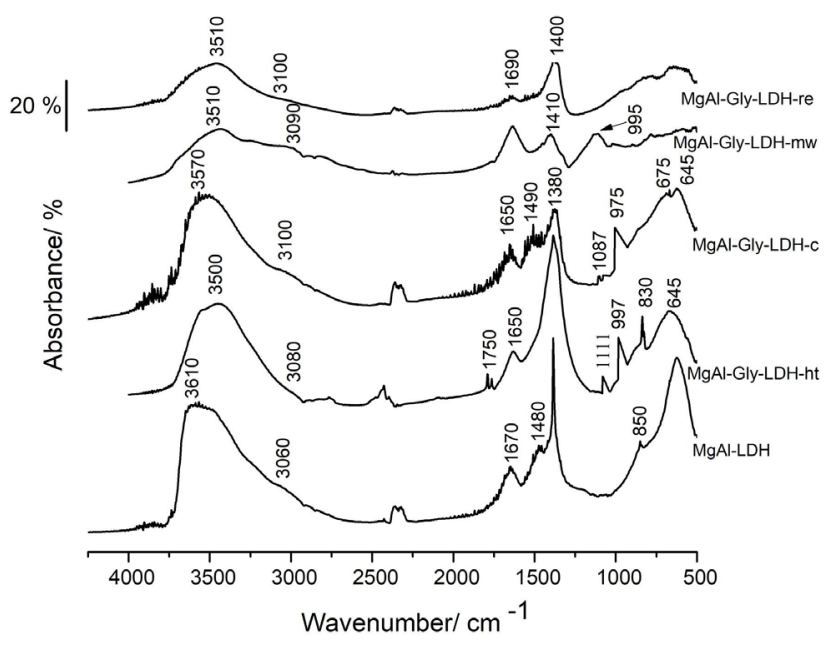

Figure 4-DRIFT spectra of the synthesized samples 
possible intercalation of the $P=O$ group into the structure (1175-1350 $\left.\mathrm{cm}^{-1}\right)$ [8]. On IR spectra for the samples of MgAl-GlyLDH-c, MgAl-Gly-LDH-ht, MgAl-Gly-LDH-mw also showed atypical peaks for LDH in the range of $900-1115 \mathrm{~cm}^{-1}$, which probably correspond to $\mathrm{PO}_{4}^{3-}\left(970-1175 \mathrm{~cm}^{-1}\right)$ and $\mathrm{PO}_{3}{ }^{2-}(910-$ $\left.1030 \mathrm{~cm}^{-1}\right)$. In addition, faint absorption bands in the range from 860 to $830 \mathrm{~cm}^{-1}$ are present in the spectra of the samples. According to the literature, they may be due to weak puckering deformations vibrations of nitrate anions $\left(860-800 \mathrm{~cm}^{-1}\right)$ or the $\mathrm{P}-\mathrm{O}$ group $\left(1200-855 \mathrm{~cm}^{-1}\right)$. The presence of these peaks serves as evidence of the complete or partial intercalation of glyphosate into the structure of the LDH. Based on the results obtained by IR Fourier spectroscopy, it can be assumed that intercalation proceeded best of all in samples of MgAl-GlyLDH-c and MgAl-Gly-LDH-ht.

Additional information on the intercalation of glyphosate anion into the structure of layered double hydroxides was obtained by using Raman spectroscopy (Figure 5). Based on official data it's known that the nitrate forms of LDH are characterized by the presence of maxima at 1044, 1355, and $712 \mathrm{~cm}^{-1}$, which correspond to variations in the $\mathrm{NO}_{3}$ group [8]. There is also a peak at $557 \mathrm{~cm}^{-1}$, which corresponds to metaloxygen-metal (Al-O-Mg) vibrations [10]. The Raman spectra of the LDH are characterized by the presence of signals in the range from $3000-4000 \mathrm{~cm}^{-1}$, which correspond to $\mathrm{OH}$ - groups of water molecules, and the presence of a peak in the region from $1300-1500 \mathrm{~cm}^{-1}$ indicates the presence of atmospheric $\mathrm{CO}_{2}$.

Previously [11], glyphosate was analyzed by Raman spectroscopy. Raman spectrum of glyphosate was obtained in the spectral range of $850-1050 \mathrm{~cm}^{-1}$. In this interval 3 maxima were recorded $\left(876 \mathrm{~cm}^{-1}, 930 \mathrm{~cm}^{-1}, 980 \mathrm{~cm}^{-1}\right)$.

The Raman spectra of all synthesized samples contain LDH's typical absorption bands. Peak's dislocation is observed on Raman spectra for all samples. The signal corresponding to the vibrations of Al-O-Mg is in the range of $555-558 \mathrm{~cm}^{-1}$ for every synthesized sample. The absorption bands corresponding to the $\mathrm{NO}_{3}$ group are also dislocated in the range of 1055$1058 \mathrm{~cm}^{-1}$. The maximum at $\sim 1055 \mathrm{~cm}^{-1}$ can be caused by both fully symmetrical stretching vibrations of the nitrate anion, and symmetrical stretching vibrations of the $\mathrm{C}-\mathrm{C}$ bond $\left(1080 \mathrm{~cm}^{-1}\right)$. It can be conceivable that takes place mutual interference of both lines, so it cannot be definitely identified. The same applies to the maxima at $\sim 1400 \mathrm{~cm}^{-1}$, as well as the corresponding fluctuations of $\mathrm{NO}_{3}-$ the group [8], which in turn corresponds to antisymmetric stretching vibrations and is pronounced due to the presence of carbonate anions.

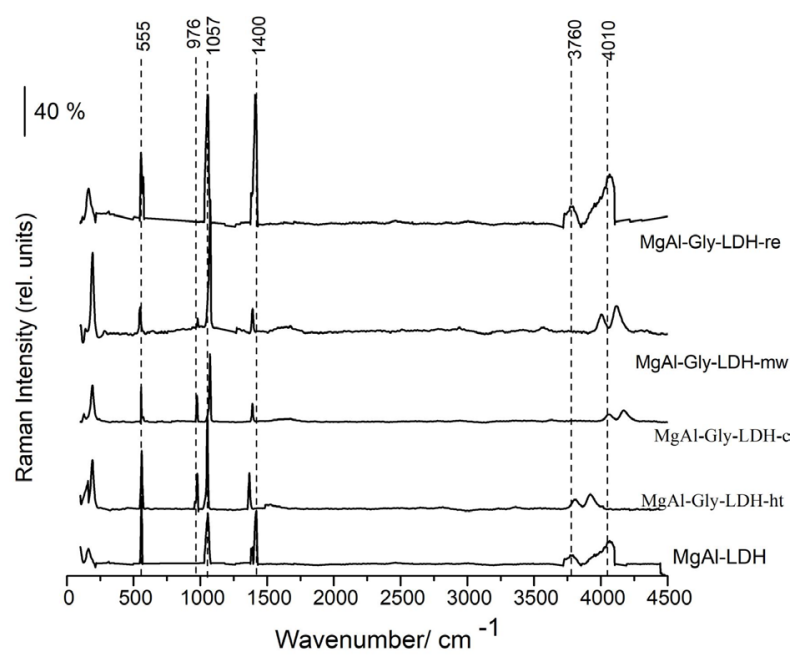

Figure 5 - Raman spectra of the synthesized samples

A peak in the range of $1350-1400 \mathrm{~cm}^{-1}$ can indicate the presence of $\mathrm{CO}_{2}$ sorbed from air. This peak is most pronounced in MgAl-Gly-LDH-re. This fact does not correspond to the result of FT-IR spectroscopy, wherein substantially no peak corresponding to atmospheric $\mathrm{CO}_{2}$.

The absorbed peak at $\sim 980 \mathrm{~cm}^{-1}$ corresponded to the $\mathrm{PO}_{3}$ group is registered for the MgAl-Gly-LDH-c, MgAl-Gly-LDH-ht, MgAl-Gly-LDH-mw samples. This peak also corresponds to the maximum related to glyphosate. In the sample MgAl-NO3-LDH and MgAl-Gly-LDH-re, this peak is completely absent, which correlates with the data obtained by FT-IR spectroscopy. The presence of this peak is proof of the intercalation of glyphosate into the LDH structure. MgAl-Gly-LDH-ht has the most pronounced peak. This fact is comparable with the results of $\mathrm{X}$-ray diffraction and IR spectroscopy.

\section{Conclusions}

MgAl-LDH-based hybrid materials with intercalated glyphosate were synthesized by co-precipitation at constant $\mathrm{pH}$, synthesis under hydrothermal conditions, rehydration method, and microwave method. Using XRD, it was shown that 
samples synthesized by co-precipitation and under hydrothermal conditions have the most crystallized structure. In a sample synthesized by the rehydration method, there are practically no phases related to $\mathrm{LDH}$. Using IR and Raman spectroscopy, partial intercalation of glyphosate into the structure of $\mathrm{LDH}$ was proved. Peaks corresponding to glyphosate were present in the spectra for all samples, except for the MgAl-Gly-LDH-re sample. According to the obtained results, it was concluded that it is possible to obtain hybrid materials with well-crystallized structure and a minimum number of impurity phases using co-precipitation and hydrothermal conditions. However, it should be noticed that the microwave method is also a very promising method for the synthesis of LDHs as it significantly reduces time of synthesis.

\section{Acknowledgment}

The present article was supported by Department of Internal and Personnel Policies on expenses from Belgorod region budget, the agreement $\mathrm{N} 58$.

The authors are grateful to the staff of the Joint Research Center "Technology and Materials", Belgorod State National Research University.

\section{References (GOST)}

1 Baylis A.D. Why glyphosate is a global herbicide: strengths, weaknesses and prospects // Pest Management Science. - 2000. - Vol.56. -299-308.

2 Cavani F., Trifiro, F. Vaccari, A Hydrotalcite-type anionic clays: preparation, properties and applications // Catalysis Today. 1991. - Vol.11. - P.173-301.

3 Forano C., Hibino T., Leroux F., Taviot-Gueho C. Layered double hydroxides in Developments in Clay Science: Handbook of Clay Science. - Vol.1, Chapter 13. - Elsevier Science, 2006. - P.1021-1098.

$4 \quad$ Khenifia A., Derriche Z., Mousty C., Prévot V., Forano C. Adsorption of glyphosate and glufosinate by $\mathrm{Ni}_{2} \mathrm{AlNO}_{3}$ layered double hydroxide // Applied Clay Science. - 2010. - Vol.47. - P.362-371.

5 Li F., Zhang L., Evans D.G., Forano C., Duan X. Structure and thermal evolution of Mg-Al layered double hydroxide containing interlayer organic glyphosate anions // Thermochimica Acta. - 2004. - Vol.424. - P.15-23.

6 Constantino V.R.L., Hnnavaia T.J. Basic properties of $\mathrm{Mg}^{2+}{ }_{1-x^{\prime}} \mathrm{Al}^{3+}{ }_{x}$ layered double hydroxides intercalated by carbonate, hydroxide, chloride, and sulfate anion // Inorganic Chemistry. - 1995. - Vol.34. - P.883-892.

7 William T., Qiwu Zh., Fumio S. Preparation of meixnerite (Mg-Al-OH) type layered double hydroxide by a mechanochemical route // Journal of Materials Science.- 2007. - Vol.42. - P.9210-9215

8 Kloprogge J.T., Wharton D., Hickey L., Frost R.L. Infrared and Raman study of interlayer anions $\mathrm{CO}_{2}{ }^{3-}, \mathrm{NO}^{-3}, \mathrm{SO}_{2}{ }^{4-}$ and $\mathrm{ClO}_{4}^{-}$in $\mathrm{Mg}^{-}$ Al-hydrotalcite // American Mineralogist. - 2002. - Vol.87. - P.623-629.

9 Nakamoto K. IR spectra and Raman spectra of inorganic and coordination compounds [IK spektry i spektry KR neorganicheskikh i koordinatsionnykh soyedineni]. - M.: Mir, 1991. - 536 p. (In Russian)

10 Dobrea I.D., Ciocan C.E., Dumitriu E., et al. Raman spectroscopy - Useful tool for studying the catalysts derived from Mo and V-oxyanion-intercalated layered double hydroxides // Applied Clay Science. - 2015. - Vol.104. - P.205-210.

11 Jin M., Song W., Liu Y., et al. Raman spectrum calculation and analysis of glyphosate // Proceedings of the International Conference on Manipulation, Manufacturing and Measurement on the Nanoscale (3M-NANO). - 2012, Shaanxi, China. - P.269-272.

\section{References}

1 Baylis DA (2000) Pest Manag Sci 56:299-308. https://doi.org/10.1002/(SICI)1526-4998(200004)56:4<299::AID-PS144>3.0.CO;2-K

2 Cavani F, Trifiro F, Vaccari A (1991) Catal Today 11:173-301. https://doi.org/10.1016/0920-5861(91)80068-K

3 Forano C (2006) Layered double hydroxides in Developments in Clay Science: Handbook of Clay Science, Elsevier Science, Vol.1, Chapter 13. P.1021-1098. https://doi.org/10.1016/S1572-4352(05)01039-1

4 Khenifia A, DerricheZ, Mousty C, Prévot V, Forano C (2010) Appl Clay Sci 47:362-371. https://doi.org/10.1016/j.clay.2009.11.055

5 Li F, Zhang L, Evans DG, Forano C, Duan X (2004) Thermochim Acta 424:15-23. https://doi.org/10.1016/j.tca.2004.05.007

6 Constantino VRL, Hnnavaia TJ (1995) Inorg Chem 34:883-892. https://doi.org/10.1021/ic00108a020

7 William T, Qiwu Zh, Fumio S (2007) J Mater Sci 42:9210-9215. https://doi.org/10.1007/s10853-007-1866-5

8 Kloprogge JT, Wharton D, Hickey L, Frost RL (2002) Am Mineral 87:623-629. https://doi.org/10.2138/am-2002-5-604

9 Nakamoto K (1991) IR spectra and Raman spectra of inorganic and coordination compounds [IK spektry i spektry KR neorganicheskikh i koordinatsionnykh soyedineniy]. Mir, Moscow, Russia. (In Russian)

10 Dobrea ID, Ciocan CE, Dumitriu E, et al (2015) Appl Clay Sci 104:205-210. http://doi.org/10.1590/1980-5373-mr-2017-1004

11 Jin M, Song W, Liu Y, Guo M, Tan Y, et al (2012) International Conference on Manipulation, Manufacturing and Measurement on the Nanoscale (3M-NANO), Shaanxi, China. P.269-272. https://doi.org/10.1109/3m-nano.2012.6472989 